\title{
INEQUALITY AND THE US IMPORT DEMAND FUNCTION
}

\author{
MARGARITA KATSIMI \\ THOMAS MOUTOS
}

\begin{abstract}
CESIFO WORKING PAPER NO. 1827
CATEgORY 6: MONETARY POLICY AND INTERNATIONAL FINANCE

OCTOBER 2006
\end{abstract}

An electronic version of the paper may be downloaded

- from the SSRN website:

- from the RePEc website:

www.SSRN.com

www.RePEc.org

- from the CESifo website: www.CESifo-group.de 


\title{
INEQUALITY AND THE US IMPORT DEMAND FUNCTION
}

\begin{abstract}
In this paper we build a model of trade in vertically differentiated products and find that income inequality can affect the demand for imports even in the presence of homothetic preferences. The empirical importance of changes in inequality on the demand for imports is then assessed by examining US data for the 1948-1996 period. Using the Johansen (1988) procedure we find that there is no evidence of a long run relationship of a standard imports equation (one including imports, income, and relative prices). However, once we include a measure of inequality in our VAR specification we find not only evidence for the existence of a cointegrating equation in imports, income, relative prices and inequality, but that the evolution of inequality has a large and positive influence on the demand for imports in the US. Moreover we find that our results are robust to alternative methods of estimating cointegration equations.
\end{abstract}

JEL Code: F13, H23, O24.

Keywords: inequality, US import demand, vertically differentiated products, cointegration.

Margarita Katsimi

Athens University of Economics and

Business

Department of International and European

Economic Studies

Patission 76

Athens 10434

Greece

mkatsimi@aueb.gr
Thomas Moutos

Athens University of Economics and

Business

Department of International and European

Economic Studies

Patission 76

Athens 10434

Greece

tmoutos@aueb.gr

July, 2006

We wish to thank to Menzie Chinn, Jaime Marquez, Nikitas Pittis and Ekaterini Panopoulou for many helpful comments and suggestions. 


\section{Introduction}

Standard specifications of import demand functions are usually based on the imperfect substitutes model, in which imports and domestically produced goods are not perfect substitutes (see, for example, Armington (1969), Goldstein and Khan (1985), Rose (1991), Hooper and Marquez (1995)). In this model, the demand for imports is usually thought of as the result of a representative household's maximization of utility (which depends on the consumption of a "domestic" and an "imported" good) subject to a budget constraint. ${ }^{1}$ The(aggregate) volume of imports is thus specified as an increasing function of aggregate income and of the ratio of domestic to imported goods prices.Implicit in this derivation of the import demand function is the idea that the distribution of income is not an important determinant of the demand for imports.

In the present paper we examine the -ceteris paribus- effects of changes in income inequality on the demand for imports. ${ }^{2}$ We do this by using a model of trade in verticallydifferentiated products in which household income determines the quality of goods demanded (Linder (1961), Flam and Helpman (1987)). ${ }^{3}$ The domestic country is assumed to have

\footnotetext{
1 In the case that the imported goods are intermediates used in domestic production, the demand for imports arises from profit maximization and it depends on relative prices and gross domestic product (e.g., Kohli (1982)).

2 Although the influence of income inequality on macroeconomic outcomes has not been an active area of research in the field of open-economy macroeconomics, the same does not hold true for the field of international trade. Indeed, there is a large theoretical and empirical literature examining the effects of inequality on trade patterns in the presence of non-homothetic preferences (e.g. Markusen (1986), Hunter (1991), Francois and Kaplan (1996), Mitra and Trindade (2003). In addition to its focus, the present paper differs from this literature in that we examine the effects of inequality in a model with homothetic preferences in the presence of vertically differentiated products.

3 Schott (2003) presents evidence that testifies to the importance of vertical intra-industry trade in the world economy. He finds that "... the relationship between unit values, exporter endowments and exporter production techniques supports the view that capital- and skill-abundant countries use their endowment advantage to produce vertically superior varieties, i.e. varieties that are relatively capital or skill intensive and possess added features or higher quality, thereby commanding a relatively high price" (Schott (2003),
} 
comparative advantage and to export to the rest of the world (ROW)), high-quality (and high-price) varieties of the differentiated product, whereas it imports low-quality (and lowprice) varieties that are consumed by low-income households. We show that mean-preserving changes in income inequality have an ambiguous effect on the demand for imports.

The flavour of the argument can be understood by the example of a hypothetical meanpreserving increase in income inequality. Let there be an income level such that all households with income up to this level (call it $\lambda$ ) maximize their utility (which depends on the quality of the vertically-differentiated product and the quantity of a homogeneous non-traded good) by purchasing low-quality, low-price imported varieties; similarly, households with incomes greater than $\lambda$ consume the high-quality domestically produced varieties. Consider now a case in which the income of some households which intially had incomes greater than $\lambda$ drops to a level below $\lambda$, whereas the incomes of some households (which initially were far greater than $\lambda$ ) rise further, so that the average income remains intact. The effect of these changes will be an increase in imports since the households for which income has dropped below $\lambda$ will switch their demand to imported varieties, whereas the households whose incomes have increased will continue to consume domestically-produced varieties. ${ }^{4}$ We trust that the reader will have by now thought of counterexamples in which a mean-preserving increase in inequality results in a reduction in the demand for imports - thus intuitively confirming the p.658). Thus, along with Bowen et al. (1987) and Trefler (1995) he concludes that there is no evidence of endowment-driven specialization across products. Moreover, Grossman (1982) has attributed a significant role to vertical product differentiation regarding the size and interpretation of estimated price and income elasticities in international trade.

${ }^{4}$ The conclusion we draw from this example would remain intact had we assumed that, in addition to the income changes mentioned earlier, the income of low-income households declined as well. Some readers may regard the hypothetical changes in household incomes specified in this example as a rough approximation of the actual changes in the US income ditribution since the mid-seventies. (see, Acemoglu (2002) for a review of the evidence). 
ambiguous effect of inequality on the demand for imports.

The theoretical ambiguity as to the effect of income inequality on the demand for imports is by no means an artifact of our assumption that the domestic country has comparative advantage in the production of high-quality varieties. Indeed, as section 2 of the paper makes clear, it would also be a feature of the model if the domestic country had comparative advantage in the production of low quality varieties. This further implies that the theoretical ambiguity would also be present if, as is the case for any country in the world in a multicommodity setting, the domestic country's comparative advantage was in high-quality varieties for only a sub-set of the differentiated products, or if international trade was conducted in both homogeneous and differentiated goods.

In the empirical section of the paper we try to ascertain the influence of changes in income inequality on the demand for US imports. For this purpose, we investigate the existence of a long run relationship between real imports, real income, relative prices and inequality for the 1948-1996 period. Using the Johansen (1988) procedure, we fail to detect evidence of a standard imports equation (one including imports, income and relative prices) The picture changes when we include a measure of inequality in our VAR specification. In fact both the trace test and the maximim eigenvalue statistic support the existence of a cointegrating vector including imports, income, relative prices and inequality. ${ }^{5}$ We also find our results to be robust to alternative methods of estimating cointegration equations, with all methods producing remarakably similar estimates of the cointegrating vector and

\footnotetext{
${ }^{5}$ Our finding about the importance of income heterogeneity in explaining the behavior of United States imports can be considered as complementary to the one advanced by Marquez (2000) in his effort to "solve" the Houthakker and Magee (1969) puzzle about the high income elasticity of US imports. Marquez argued (and provided the relevant evidence) that if immigrants retain their tastes for their native products, then an increase in immigration would increase the demand for imports.
} 
providing estimates of the elasticity of imports with respect to inequality ranging from 0.8 1.2. Moreover, given that the efficiency of the various methods in small samples may differ considerably, we perform a small Monte Carlo experiment in order to assess their relative performance in small samples. We conclude that the Johansen procedure along with the Fully Modified Least Squares estimator of Phillips and Hansen (1990) seem to perform best both in terms of bias and variation. Interestingly, these two methods deliver the highest estimates of the inequality elasticity.

Our estimates suggest a significant impact of inequality on real imports. For example, according to our range of estimates (0.8-1.2), had inequality in the US remained at its 1975 level, imports in 1996 would have been lower between 12 and 19 percent of the fitted value (which is close to the actual value). The further rise in inequality since 1996 implies that had inequality in 2004 been at its 1975 level, the percentage decline in US imports in 2004 would have been even larger than in 1996, thus implying a very large improvement in the US current account deficit. ${ }^{6}$

The remainder of the paper is as follows: Section 2 develops the theoretical model showing the influence of income inequality on the demand for imports. The empirical analysis is presented and discussed in section 3. The last section concludes.

\section{The model}

We present a simple theoretical framework capable of illustrating the influence of income inequality on the demand for imports. The framework is akin to Katsimi and Moutos (2005),

\footnotetext{
${ }^{6}$ Although recent data on US income inequality exist, in our empirical analysis we use the longer data set available, which covers the 1944-1996 period.
} 
which has in turn borrowed from Malley and Moutos(2002) and Flam and Helpman (1987). We will assume the existence of a small open economy, which produces (and consumes) two goods: a homogeneous non-traded good $(X)$ and a vertically-differentiated product $(Y)$ that is traded with the rest of the word (ROW). The model features two-way international trade in the vertically-differentiated good, with the domestic country producing (and exporting) a high-quality quality variety of good $Y$, and importing a low-quality variety of it.

\section{$2.1 \quad$ Firms}

Good $X$ (the non-traded good) is a homogeneous good produced under perfectly competitive conditions in the domestic country with the use of labour services $(L)$. We conceive of $L$ as being the simple aggregate of effective labour services provided by perfectly substitutable workers with each of them possessing different units of effective labour. ${ }^{7}$ We assume that firms pay the same wage rate per effective unit of labour - thus the distribution of talent across firms does not affect unit production costs. For simplicity, we assume that each unit of $L$ produces one unit of the homogeneous good.under linear technology,

$$
X=L
$$

Using labour as the numeraire, we get that the price of the homogeneous, non-traded good is, $P_{X}=1$. We assume that all prices in the domestic economy and in the ROW are expressed in a common currency (the exchange rate is fixed at unity).

\footnotetext{
7 Alternatively, we could conceive of $L$ as a function of the quantities of labour provided by imperfectly substitutable groups of workers, e.g., $L=f\left(L_{S}, L_{U}\right)$, where $L_{S}$ and $L_{U}$ stand for the effective units of skilled and unskilled labour. Under the interpretation adopted in the text, changes in (income) inequality can be the result of changes in the effective number of labour units each worker (cum household) is endowed with. Under the skilled-unskilled workers interpretation, changes in inequality can be the result of changes in the relative wage of skilled workers - the so-called skill premium. Although empirically the second interpretation may be more relevant (especially for the United States - see, for example, Acemoglu (2002)), it is analytically far simpler to consider the first case of perfectly substitutable workers with unequal endowments of effective labour units.
} 
The vertically-differentiated good $(Y)$ is produced by perfectly competitive firms in both the domestic country and the ROW. We assume that quality is measured by an index $Q>0$, and that there is complete information regarding the quality level inherent in all varieties produced at home and abroad. Moreover, for simplicity, ${ }^{8}$ we assume that there is only one variety offered by domestic firms, $q$, and only one variety offered by ROW firms, $q^{*}$, with $q>q^{*}$. We further assume that, in both the domestic country and the ROW, average costs depend on quality, and that each (physical) unit of a given quality is produced at constant cost. The dependence of average costs on quality is motivated by the fact that increases in quality - for a given state of technological capability - involve the "sacrifice" of an increasing number of personnel which must be allocated not only to the production of a higher number of features attached to each good (e.g., electric windows, air bags, ABS, etc. in the case of automobiles) but also to the development and refinement of these features as well.

We assume that the domestic country has comparative advantage in the production of the high quality variety of the differentiated good. This implies that the least cost producers of the variety with quality $q$ are domestic producers (that is, $A C(q)<A C^{*}(q)$ ), whereas the least cost producers for variety $q^{*}$ are ROW producers (i.e., $A C\left(q^{*}\right)>A C^{*}\left(q^{*}\right)$ ). For simplicity, we set $P(q)=A C(q)=\gamma q$, and $P\left(q^{*}\right)=A C^{*}\left(q^{*}\right)=\gamma^{*} q^{*}$, with $\gamma, \gamma^{*}>0$.Changes in $\gamma, \gamma^{*}$ may, for example, occur either due to cost-changing process innovations, or due to changes in the macroeconomic environment (e.g.the exchange rate).

\footnotetext{
8 Katsimi and Moutos (2005) present a model in which there is a continuum of domestic and foreign varieties offered to the domestic country consumers.
} 


\subsection{Households}

All households are assumed to have identical preferences, and to be endowed with one unit of labour, which they offer inelastically. There are, however, differences in skill between households, which are reflected in differences in the endowment of each household's effective labour supply. This is in turn reflected in an unequal distribution of income across households. Following Rosen (1974) and Flam and Helpman (1987) we assume that the homogeneous good is divisible, whereas the quality-differentiated product is indivisible and households can consume only one unit of it. For simplicity, and in order to demonstrate that inequality can have an influence on the demand for imports even with homothetic preferences,${ }^{9}$ we write the utility function of household $i$ as

$$
U_{i}=Q_{i} X_{i}
$$

where $Q_{i}$ and $X_{i}$ stand for the quality (either $q$ or $q^{*}$ ) of the differentiated product and the quantity of the homogeneous good (respectively) consumed by household $i^{10}$

Let $e_{i}$ stand for the endowment of effective labour units owned by household $i$. Since the wage rate per effective unit of labour is unity, $e_{i}$ stands also for household income. Assume that there is a continuum of households, $i \in[0,1]$, with Pareto distributed incomes. The Pareto distribution is defined over the interval $e \geq b$, and its CDF is

$$
F(e)=1-\left(\frac{b}{e}\right)^{a}
$$

\footnotetext{
${ }^{9}$ An implication of Krugman's (1989) derivation of the import demand function, is that with homothetic preferences, changes in inequality will not have any effect on the demand for imports if trade is conducted in horizontally differentiated products, since changes in household income would not alter the proportion of spending that either poorer or richer households spend on imported varieties.

${ }^{10}$ We implicitly assume that there is a fixed (and common across households) disutility of work effort which enters additively in the utility function. We also assume that the lowest ability household gets a higher level of utility (due to consumption) from working rather than from sitting idle.
} 
where $a>1$.Parameter $b$ stands for the lowest income (ability) in the population, and parameter $a$ determines the shape of the distribution (higher values of $a$ imply greater equality). The mean of the Pareto distribution is equal to

$$
\mu=\frac{a b}{a-1}
$$

The budget constraint of a household depends on whether it consumes the domestic or the foreign variety of the differentiated product. The budget constraint of a household which buys the domestically-produced variety is,

$$
e_{i}(1-t)=X_{i}+\gamma q
$$

whereas the budget constraint of a household buying the imported variety is,

$$
e_{i}=X_{i}+\gamma^{*} q^{*}
$$

where $t$ stands for the (linear) income tax rate, and $\tau$ for the ad-valorem tariff rate. ${ }^{11}$ As a result, the utility maximizing demand for the homogeneous good if the household chooses to consume the domestically-produced variety is,

$$
X_{i}^{D}=e_{i}-\gamma q
$$

whereas if the household chooses to consume the ROW-produced variety the demand for $\mathrm{X}$ is,

$$
X_{i}^{F}=e_{i}-\gamma^{*} q^{*}
$$

${ }^{11}$ We assume that for all relevant values of the tariff rate $\tau$, it will never be possible for domestic producers to supply to the domestic market the variety $q^{*}$ at a lower price than the (inclusive of the tariff) price at which the ROW producers can sell the good to domestic consumers. 
In deriving the above we have assumed that for all households income is high enough to generate positive demands for both goods. The resulting indirect utility functions in the two cases are then,

$$
\begin{gathered}
V_{i}^{D}=\left(e_{i}-\gamma q\right) q \\
V_{i}^{F}=\left(e_{i}-\gamma^{*} q^{*}\right) q^{*}
\end{gathered}
$$

Household $i$ will buy a foreign produced variety if $V_{i}^{F}>V_{i}^{D}$. We note that $\vartheta\left(V_{i}^{D}-\right.$ $\left.V_{i}^{F}\right) / \vartheta e_{i}>0$, i.e. the difference between $V_{i}^{D}$ and $V_{i}^{F}$ is increasing in household income. This implies that only households with large incomes will be willing to buy the high-quality variety which is domestically produced, whereas low-income households will find it optimal to consume the low-quality variety which is imported from the ROW. In Figure 1, high income households face the budget constraint BC1 and achieve higher utility at point 1 (by consuming the domestically produced variety) rather than at point 2 (which is associated with the foreign-produced variety). On the other hand, low income households bace the budget constraint BC3 and prefer to consume the imported variety (point 3) rather than the domestically produced one (point 4). Finally, there exist households with income $\lambda$, depicted by $\mathrm{BC} 2$, which are indifferent between the domestically produced and the imported varieties ( points 5 and 6$)$.

Let $\lambda$ denote the income of a household that is indifferent between consuming the domestically produced variety and the foreign variety, i.e., for this household it holds that

$$
V^{D}=(\lambda-\gamma q) q=\left(\lambda-\gamma^{*} q^{*}\right) q^{*}=V^{F}
$$




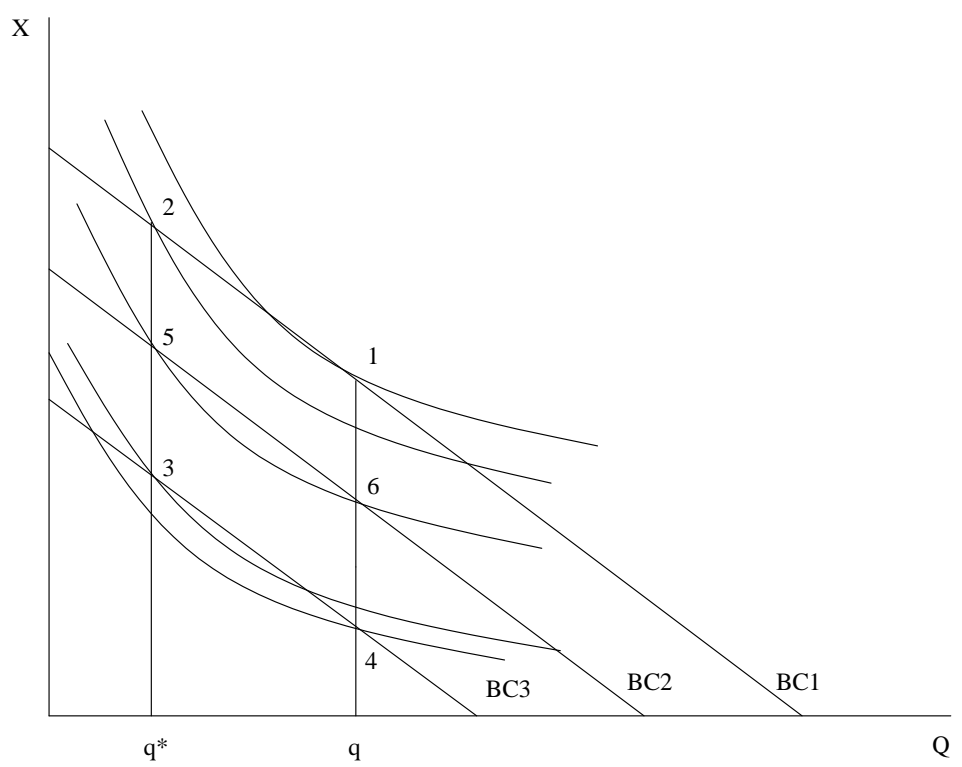

Figure 1: The relationship between income and inequality

We term $\lambda$ the dividing level of income (ability). Solving for $\lambda$ we find that

$$
\lambda=\frac{\gamma q^{2}-\gamma^{*}\left(q^{*}\right)^{2}}{q-q^{*}}
$$

Equation (12) indicates that the value of $\lambda$ is independent of both parameters $(a$ and $b)$ describing the distribution of income. It depends only on domestic and ROW costs and the associated quality levels.

The Pareto distribution implies that the proportion of households with incomes smaller or equal to $\lambda$ (that is, the proportion of households which choose to consume the foreignproduced variety), is equal to $1-(b / \lambda)^{a}$. Thus, the real value (volume) of total imports is

$$
M=\left[1-(b / \lambda)^{a}\right] \gamma^{*} q^{*}
$$

Given our interest in the effect of mean preserving changes in income inequality, and the 
independence of $\lambda$ from changes in $a$ and $b$, we can use equation (13) to find the effect of changes in $a$ while adjusting $b$ (the lowest income in the population) so as to keep average income $(=b a /(a-1))$ constant. ${ }^{12} \quad$ Letting $\bar{\mu}$ denote the given level of average income, we find that

$$
\frac{\vartheta M}{\vartheta a}=\left(M-\gamma^{*} q^{*}\right)\left[\ln \left(\frac{(a-1) \bar{\mu}}{a \lambda}\right)+\frac{1}{a-1}\right]
$$

The sign of $\vartheta M / \vartheta a$ is ambiguous, since $\ln ((a-1) \bar{\mu} / a \lambda)=\ln (b / \lambda)<0 .{ }^{13}$

In order to understand the reason for this ambiguous effect consider first the result of a rise in $a$ while holding $b$ constant. In this case the rise in $a$ (which implies a reduction in inequality) is associated with a reduction in average income (ability) and in the proportion of households with income greater than $\lambda$ (i.e. the households buying the domestically produced variety). As a result, the proportion of households choosing to buy domestically produced goods decreases and imports increase (see also equation (11)). Given our wish to examine the effects of mean preserving changes in income inequality, an increase in $a$ must be paired with an increase in $b$ in order to keep $\mu$ constant. A -ceteris paribus- increase in the scale parameter $b$ (which impies a rise in the lowest income in the population, as well as a rise in average income) implies that there will be fewer households below any given level of $\lambda$, thus decreasing the proportion of households buying the imported variety. This implies that the CDFs representing the two income distributions will be intersecting, with the one associated

${ }^{12}$ As can be easily seen from equation (13) a rise in equality (with $b$ given) results in a rise in imports, i.e.

$$
\frac{\vartheta M}{\vartheta a}=-\left[\frac{b}{\lambda}\right]^{a} \gamma^{*} q^{*} \ln \left[\frac{b}{\lambda}\right]>0,
$$

This results because the rise in $a$ causes a fall in average income and a corresponding rise in the proportion of households wishing to consume imported varieties.

${ }^{13}$ Note also that equation (13) implies that $M-\gamma^{*} q^{*}<0$. 


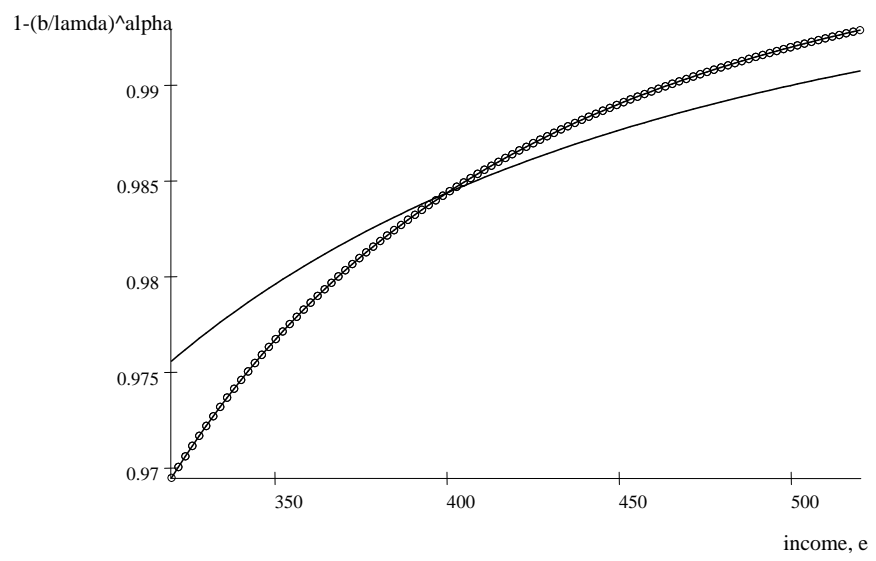

Figure 2: Inequality and the CDF

with higher values of $a$ and $b$, crossing from below the one represening lower values of these parameters. Figure 2 focuses on the intersection of two alternative CDFs . The solid curve depicts the CDF for $a=2$ and $b=50$, whereas the dotted bold curve represents the CDF for the same average income $(\mu=100)$ for $a=3$ and $b=100$. Thus, if the value of $\lambda$ is lower (higher) than the level of income at which the two CDFs intersect, a rise in $a$ from 2 to 3 (accompanied by a rise in $b$ from 50 to 100) will reduce (increase) the proportion of households wishing to buy imported varieties, and imports will decrease (increase).

The theoretical ambiguity as to the effect of a mean preserving increase in inequality on the volume of imports which exists in the present model is also a feature of more complicated models (e.g. in models allowing for a continuum of varieties to be offered by domestic and ROW producers, or for the presence of imported intermediate inputs). It would also be 
present if the domestic country had comparative advantage in the production of the lowquality variety. This can be easily verified by noting that in this case equation (12) would be modified to $M=(b / \lambda)^{a} \gamma^{*} q^{*}$, since in this case the imported variety would be bought by households with income greater than (or equal to) $\lambda$.

However, changes in actual income distributions may not be as "smooth" as described by varying the parameters of theoretical distributions. Consider, for example, the case of a rise in inequality which involves the reduction of the income of some households -which initially had incomes slightly larger than $\lambda$ - to less than $\lambda$, and the concurrent rise of the incomes of households with incomes significantly greater than $\lambda$ so that average income says constant. Our analysis would then predict an unambiguous effect on the demand for imports; since the households whose incomes have been reduced to less than $\lambda$ will switch their demand from the domestically-produced variety to the foreign-produced one, the demand for imports will increase. ${ }^{14}$ Since it is also easy to construct other hypothetical examples in which a rise in inequality results in a fall in import demand, we proceed with the empirical examination of this issue.

\section{Econometric Analysis}

\subsection{Empirical Literature Review and Data}

We aim at analyzing empirically the impact of US inequality on the US demand for imports. Most empirical studies on the macroeconomic determinants of the demand for imports estimate a standard real import demand function according to which imports depend on real income and relative prices. A large body of empirical literature has estimated price and in-

\footnotetext{
${ }^{14}$ The households whose income rises and remains higher than $\lambda$ will continue to consume the domestically produced variety.
} 
come elasticities of imports and much of it focused on US trade. ${ }^{15}$ More recent papers have attempted to find evidence of a long run relationship (cointegration) between the levels of imports, income and relative prices (or the real exchange rate). The results are mixed. Rose and Yellen (1989) and Meade (1992) fail to find evidence of cointegration for the 1960-87 period. Johnston and Chinn (1996) find a cointegrating relationship by excluding agricultural products and fuels for the 1973-95 period whrereas Chinn (2005b) obtains evidence of a cointegrating relationship only when excluding computers. Boyd et al. (2001) obtain a long run import demand function for the 1975-95 period but they impose the restriction that the income elasticity of imports should equal the income elasticity of exports with the opposite sign. Finally, Hooper et al. (1998) find evidence for a cointegrating relationship among real imports, real income and relative prices for the 1960-1994.

Another strand of this literature challenges the conventional wisdom by arguing that the standard imports demand function may be misspecified due to the ommission of other determinants of a long run imports equation. Along these lines, Marquez (2000, 2002) provides evidence for a cointegrating imports equation for the 1967-1997 period by including either the share of immigrants in the population or the ratio of the foreign capital stock to the US capital stock. The inclusion of immigration is based on his argument that if immigrants retain their tastes for their native products, then an increase in immigration would increase the demand for imports. On the other hand, as argued by Helkie and Hooper (1988), the inclusion of the relative capital stock is a measure of an existing upward bias in import prices. This bias is the result of the failure of import prices to incorporate the prices of new products

\footnotetext{
${ }^{15}$ For surveys of literature on this topic see Goldstein and Kahn (1985) and Sawyer and Springle (1996).
} 
which are most of the times lower that the prices of existing products.

The main empirical implication of our theoretical model is that inequality may be an important determinant of the demand for imports. As a result, ommitting the level of inequality may be one reason why most previous studies failed to provide strong evidence of a stable long run import demand function. Our purpose is to enrich the commonly used empirical specification by including a measure of inequality. Specifically, in line with the most recent research in this topic, we use the Johansen $(1988,1991)$ procedure in order to investigate the existence of a long-run relationship between imports, income, relative prices and inequality. We expand on this traditional specification since -unlike our stylized modelinternational trade is conducted not only in vertically differentiated goods but in horizontally differentiated and homogeneous goods as well.

Our analysis is based on annual data since there are no higher frequency data for inequality. We model US real imports of goods and services $(I M)$ as a function of US real GDP $(Y)$, the relative price of imports $(R P)$ and inequality $(I N)$, where all variables are in logs. ${ }^{16}$ Our measure of ineq uality is taken from the revised version of World Income Inequality Dataset (WIID) constructed by Deininger and Squire (1996). This data set is to our knowledge the most complete and reliable source of inequality data and it provides alternative estimates for the US GINI coefficient. We measure inequality, IN with the GINI coefficient that covers

\footnotetext{
${ }^{16}$ Note that in equation (13), the effect of changes in income and relative prices are captured through changes in the parameters $a, b, q, q^{*}, \gamma$, and $\gamma^{*}$.In this respect it is important to note that in our theoretical analysis labour is assumed to be the only domestically owned factor of production. Nevertheless, since household consumption choices are made on the basis of total household income, rather than income derived from the sale of the household's labour services alone, care must be taken to control for the other sources of income. Also, the presence of not only final consumption goods but of intermediate inputs as well as homogeneous and horizontally differentiated consumption goods in the actual import data necessitates the inclusion of a variable measuring aggregate domestic activity. We use domestic GDP to control for the influence of the above concerns.
} 
the longest period (1944-1996) constructed by Brandolini (1998). Real imports, IM and real GDP, $Y$ are both in 2000 chain weighted dollars from the Federal Reserve Bank of St. Louis. Following Hooper et al (1998) we use the price of imports over the GDP deflator, $R P$ from the International Financial Statistics as our main measure of competitiveness. All variables exist after 1948. In many empirical studies competitiveness is measured with some exchange rate index such as the real effective exchange rate or some trade weighted exchange rate. Therefore, in an alternative specification we also use the real effective exchange rate, $R E R$ from the OECD Economic Outlook as a measure of competitiveness. However, given that real exchange rate data exist only after 1970 this alternative specification reduces our sample from the 1948-1996 period to the 1970-1996 period.

\subsection{Estimation and Testing Procedure}

First, we test the unit root hypothesis for each of the individual component of the vector stochastic process $\left\{Z_{t}\right\}$, where $Z_{t}^{\prime}=\left(I M_{t} Y_{t} R P_{t} I N_{t}\right)$. Standard unit root tests of Dickey and Fuller (1981) and Phillips and Perron (1988?) fail to reject the unit root null for all the four series under consideration. Note that this evidence is robust to the choice of the lag-length in the Dickey-Fuller regressions and the choice of the bandwidth parameter in the context of the Phillips-Perron non-parametric procedure. Therefore, we proceed by assuming that the process $\left\{Z_{t}\right\}$ consists of $I(1)$ components. Then we move on to multivariate analysis within the Johansen $(1998,1991)$ cointegration framework. We take the following steps: (i) Since the Johansen procedure is based on the estimation of a VAR(p) model, we first, we choose the optimal lag length of the VAR. (ii) In the context of the Vector Error Correction (VEC) representation of $\operatorname{VAR}(\mathrm{p})$, we test for cointegration by using the trace and the maximum 
eigenvalue statistic. (iii) Having determined the cointegration rank, we re-estimate the VEC model with the cointegration rank restriction imposed on the long-run matrix of the model. In this framework, we estimate both the long-run and the short-run dynamics of the system. More specifically, let us assume that the stochastic process $\left\{Z_{t}\right\}$, where $Z_{t}^{\prime}=\left(I M_{t} Y_{t} R P_{t}\right.$ $\left.I N_{t}\right)$, is generated by the following $\operatorname{VAR}(\mathrm{p})$ model

$$
Z_{t}=A_{0}+\sum_{i=1}^{p} A_{i} Z_{t-i}+U_{t}
$$

whose VEC representation takes the form:

$$
\Delta Z_{t}=A_{0}+\Pi Z_{t-1}+\sum_{i=1}^{p-1} \Gamma_{i} \Delta Z_{t-i}+U_{t}
$$

with $U_{t} \sim N I(0, \Omega)$. The process $\left\{Z_{t}\right\}$ is cointegrated if the matrix $\Pi$ is of reduced rank, that is when $r(\Pi)=r<4$ in our case. The rank of $\Pi$ describes the number of the cointegrating vectors in the system. If the matrix $\Pi$ is of full rank, that is $r(\Pi)=r<4$ then the $\operatorname{VAR}(\mathrm{p})$ is stable VAR in levels and there are no unit roots in the system. Note that this case contradicts the assumption that each of the four series is $\mathrm{I}(1)$. Finally, if $r(\Pi)=0$ then the number of unit roots in the system is equal to four, and the series are not cointegrated. Let us assume that $r(\Pi)=1$. In such a case, the long-run matrix $\Pi$ can be decomposed into

$$
\Pi=\mathbf{c b}^{\prime}
$$

where $\mathbf{c}$ and $\mathbf{b}$ are $(4 \times 1)$ vectors. In such a case, the system (16) becomes

$$
\Delta Z_{t}=A_{0}+\left[\begin{array}{c}
c_{11} \\
c_{21} \\
c_{31} \\
c_{41}
\end{array}\right]\left[\begin{array}{llll}
b_{11} & b_{21} & b_{31} & b_{41}
\end{array}\right] Z_{t-1}+\sum_{i=1}^{p-1} \Gamma_{i} \Delta Z_{t-i}+U_{t}
$$


It can be seen that the vector $\mathbf{b}$ contains the long-run parameters of the system, whereas the vector $\mathbf{c}$ contains the adjustment coefficients of each of the four variables $I M_{t} Y_{t} R P_{t} I N_{t}$ to the disequilibrium error of the of the previous period.

\subsection{Results}

We use the Johansen (1988), and Johansen and Juselius (1990) procedure in order to test for cointegration and to determine the number of long-run relations. We choose the 2 lag specification for our VAR since the 1 lag specification suffers from serial correlation. Our results are reported in Table 1 . We first examine whether in the absence of the inequality variable there is cointegration among real imports, real GDP and relative prices. As can be seen from column (1), there is no evidence of cointegration among $I M, Y$ and $R P$. The inclusion of inequality as an additional determinant of the volume of imports provides us with evidence of cointegration according to both the trace test and the maximal eigenvalue statistics - see column (2). ${ }^{17}$ All reported coefficients (the elements of the cointegration vector b) are significant. The income elasticity of imports is 1.6, lower than the estimates reported by Chinn (2005a). The relative price sensitivity is 0.15 and has the expected negative sign. Inequality has a positive and significant effect on imports.

\footnotetext{
17 The cointegrating equation reported in Table 1 does not include a time trend. Nevertheless, even if we include a time trend in the regressors of column (2), we still get a cointegrating vector according to the trace test.
} 
TABLE 1: Import Cointegration Results I

\begin{tabular}{|c|c|c|c|}
\hline \multirow{2}{*}{$\begin{array}{l}\text { Long Run } \\
\text { Coefficients, } \zeta_{i}\end{array}$} & \multicolumn{3}{|c|}{ US real imports, $I M$} \\
\hline & (1) & $(2)$ & $(3)$ \\
\hline \multicolumn{4}{|c|}{ Cointegr. vectors: } \\
\hline trace test & 0 & 1 & 1 \\
\hline max. eigenvalue & 0 & 1 & 1 \\
\hline$Y$ & $\begin{array}{l}1.980 \\
(0.080)\end{array}$ & $\begin{array}{l}1.614 \\
(0.181)\end{array}$ & $\begin{array}{l}1.11 \\
(0.076)\end{array}$ \\
\hline$R P$ & $\begin{array}{c}-0.345 \\
(0.227)\end{array}$ & $\begin{array}{c}-0.155 \\
(0.046)\end{array}$ & \\
\hline$I N$ & & $\begin{array}{l}1.220 \\
(0.189)\end{array}$ & $\begin{array}{c}3.03 \\
(0.289)\end{array}$ \\
\hline$R E E R$ & & & $\begin{array}{c}-0.11 \\
(0.04)\end{array}$ \\
\hline constant & -11.00 & -12.38 & -14.05 \\
\hline lag & 2 & 2 & 1 \\
\hline $\mathrm{N}$ & 46 & 46 & 25 \\
\hline \multicolumn{4}{|c|}{ Error correction coefficients } \\
\hline$I M$ & & $\begin{array}{c}-0.638 \\
(0.181)\end{array}$ & $\begin{array}{c}-0.873 \\
(0.362)\end{array}$ \\
\hline$Y$ & & $\begin{array}{c}-0.169 \\
(0.09)\end{array}$ & $\begin{array}{c}-0.070 \\
(0.125)\end{array}$ \\
\hline$R P$ & & $\begin{array}{c}0.592 \\
(0.22)\end{array}$ & \\
\hline$I N$ & & $\begin{array}{l}0.167 \\
(0.06)\end{array}$ & $\begin{array}{c}-0.075 \\
(0.089)\end{array}$ \\
\hline$R E E R$ & & & $\begin{array}{c}-0.602 \\
(0.230)\end{array}$ \\
\hline
\end{tabular}

Notes: Standard errors in parentheses.

Column (3) of Table 1 reports estimates using the real exchange rate, $R E E R$ as an 
alternative measure of competitiveness. Again, a long run relationship is detected only after the inclusion of inequality, $I N$ among the determinants of the volume of imports in a $\operatorname{VAR}(1)$ specification. In this case, the income elasticity is close to unity whereas inequality has an even stronger impact on imports. However, as in Hooper et al (1998), we obtain an incorrect sign for the real exchange rate elasticity. The error correction coefficients of real imports reported in the last two columns of Table 1 are negative and significant under both specifications. This indicates that in the presence of disequilibrium the volume of imports gradually adjusts towards its long-run value. Finally, the residuals of both models satisfy homoskedasticity, and normality. However, the residuals of model (3) suffer from serial correlation.

In order to get an idea for the importance of inequality in shaping the evolution of US imports, we depict in Figure 3 the fitted values of imports derived from the long run imports equation shown in column (2) of Table 1 (series 1), whereas series 2 represents the fitted values of imports which would obtain had inequality remained constant at its 1975 level. Series 3 depicts the actual evolution of US imports. According to our estimates, had inequality remained at its 1975 level, the fitted value of imports in 1996 would have been $19 \%$ lower than the fitted value of imports derived by using the actual level of inequality for 1996. The further rise in inequality since 1996 depicted by more recent but shorter data sets (see Current Population Survey, U.S. Census Bureau), implies that had inequality in 2004 been at its 1975 level, the percentage decline in US imports in 2004 would have been even larger than in 1996, thus implying a very large improvement in the current account deficit. 


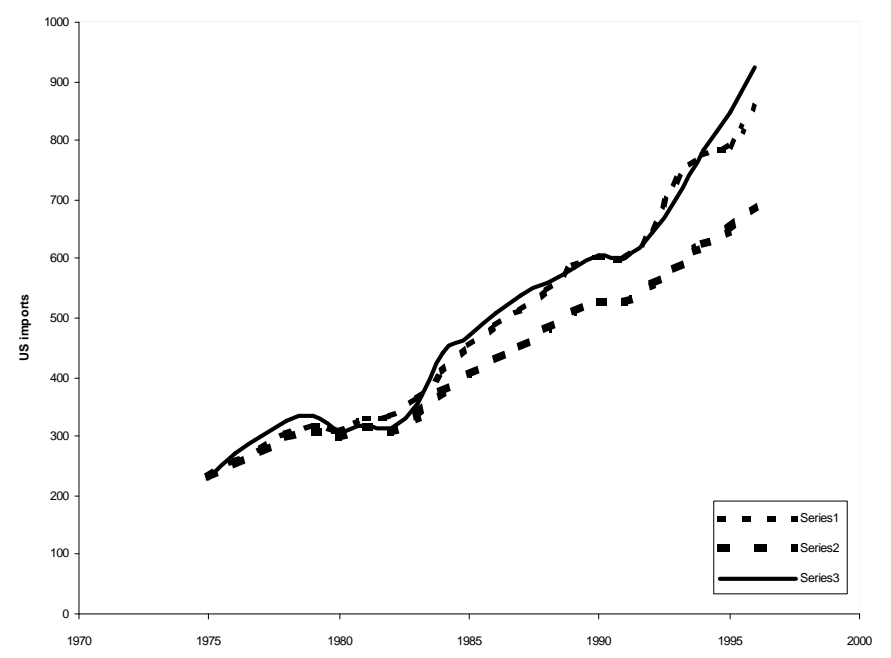

Figure 3: US imports

\subsection{Robustness}

In this section we address the following questions:

(i) How robust are our empirical results to the choice of the cointegration estimation method? In other words, how different would our results be if we adopted other asymptotically efficient cointegration estimators?

(ii) The Johansen cointegration method is asymptotically optimal. However, in samples as small as ours (46 observations) it has been reported that the Johansen method as well as other asymptotically equivalent methods suffer from small sample bias [see Hargreaves, (1994), Inder (1993) and Gonzalo (1994)]. This bias depends on the dynamics of the system. For example in the context of the triangular model of cointegration of Phillips (1991) this bias depends on the Granger causality structure between the cointegration error and the 
error that drives the regressor and the serial correlation properties of the former.

To address these questions we take the following two steps: First, since our previous results indicate a single cointegrating vector, we estimate our model with two other asymptotically efficient single equation cointegration methods. Second, we perform a small Monte Carlo experiment to assess the relative performance of the alternative estimators for a sample equal to that used in the estimation and a Data Generation Process which resembles as closer as possible the one that is likely to have given rise to the observed data.

\subsubsection{Alternative cointegration methods}

As far as cointegration estimators are concerned we consider, apart from the Johansen procedure $(\mathrm{JOH})$ described in the previous section, the following estimators: (i) The simple OLS which is not asymptotically efficient but is included as a benchmark. (ii) the Autoregrssive Distributed Lag estimator (ARDL) suggested by Pesaran and Y. Shin (1999) (see also Phillips and M Loretan (1991) for a version of ARDL) (iii) the semi-parametric Fully Modified Least Squares (FMLS) estimator of Phillips and Hansen (1990) The difference between FMLS and ARDL(p,q,k) lies in the way the 'long-run correlation' and 'endogeneity' cointegration effects are accounted for. In particular, FMLS generates estimates of the nuisance parameters present in the asympotic distribution of OLS non-parametrically, whereas ARDL eliminates the nuisance parameters from the limiting distributions by estimating a full dynamic model including lags and leads of the variables in the system (see Pesaran and Shin (1999), and Panopoulou and Pittis (2004)).

Table 2 presents the results for these alternative cointegration estimators. These results should be compared with those reported in the second column of Table 1. This comparison 
reveals that our results are robust across the different methods: not only all coefficients are significant and of the same sign independently of the estimation method used, but also the income and relative price elasticities vary very little across all estimation methods. We also observe that the inequality elasticity of imports increases from 0.8 to 1.2 when the Johansen and FMLS are used. However, even under the lower elasticity, the effect of the rise in US inequality on US imports would still be very large - it would imply that imports in 2004 would have been lower by about $12 \%$ of their 1996 value (25\% of their 2004 value) had inequality remained at its 1975 level.

\section{TABLE 2 : Import Cointegration Results II}

\begin{tabular}{|c|c|c|c|}
\hline \multirow[b]{2}{*}{ Method } & \multicolumn{3}{|c|}{ US real imports, $I M$} \\
\hline & OLS & $\mathrm{ARDL}^{*}$ & FMLS $^{* *}$ \\
\hline$Y$ & $\begin{array}{l}1.707 \\
(0.02)\end{array}$ & $\begin{array}{l}1.747 \\
(0.046)\end{array}$ & $\begin{array}{l}1.683 \\
(0.019)\end{array}$ \\
\hline$R P$ & $\begin{array}{c}-0.170 \\
(0.045)\end{array}$ & $\begin{array}{c}-0.252 \\
(0.100)\end{array}$ & $\begin{array}{c}-0.244 \\
(0.041)\end{array}$ \\
\hline$I N$ & $\begin{array}{l}0.784 \\
(0.166)\end{array}$ & $\begin{array}{l}0.861 \\
(0.346)\end{array}$ & $\begin{array}{l}1.24 \\
(0.155)\end{array}$ \\
\hline constant & $\begin{array}{c}-11.58 \\
(0.530)\end{array}$ & $\begin{array}{c}-12.18 \\
(1.123)\end{array}$ & $\begin{array}{l}-13.04 \\
(0.488)\end{array}$ \\
\hline $\mathrm{N}$ & 49 & 48 & 48 \\
\hline
\end{tabular}

Notes: Standard errors in parentheses,

* The Schwartz Order Selection Criterion suggested one lag of $I M$ and one lag of $Y$. No time trend is included.

** Bartlett weights have been used. A truncation lag of 8 has been selected. 8 is the lag that, according to the Monte Carlo experiment of the following section, eliminates the bias for this parameters configuration.

Still since the rise of the GINI elasticity is realtively large when either the JOH or FMLS 
procedures are employed, a natural question to ask is which estimate we trust. This question cannot be answered by appealing to asymptotic arguments, since all the three estimators (JOH, ARDL, FMLS) are asymptotically equivalent. Therefore, in order to assess the relative performance of the alternative estimators, we proceed to Monte Carlo simulations. In the following section we run a small Monte Carlo experiment for a sample equal to that used in the estimation (49 observations) and a Data Generation Process which resembles as close as possible the one that is likely to have given rise to the observed data.

\subsubsection{A Monte Carlo experiment}

We shall assess the performance of these estimators in the context of the triangular model of cointegration suggested by Phillips (1991). In our case and assuming that the cointegration error and the errors that drive the regressors follow a $\operatorname{VAR}(1)$ model, we have

$$
\begin{gathered}
y_{t}=c+\mathbf{b}^{\top} \mathbf{x}_{t}+u_{1 t} \\
\mathbf{x}_{t}=I_{3} \mathbf{x}_{t-1}+\mathbf{e}_{t} \\
{\left[\begin{array}{l}
u_{1 t} \\
\mathbf{e}_{t}
\end{array}\right]=\left[\begin{array}{ll}
a_{11} & \mathbf{a}_{12}^{\top} \\
\mathbf{a}_{21} & A_{22}
\end{array}\right]\left[\begin{array}{l}
u_{1 t} \\
\mathbf{e}_{t-1}
\end{array}\right]+\left[\begin{array}{l}
\nu_{1 t} \\
\boldsymbol{\nu}_{t}
\end{array}\right]}
\end{gathered}
$$

and

$$
\left[\begin{array}{c}
\nu_{1 t} \\
\boldsymbol{\nu}_{t}
\end{array}\right] \sim N I I D\left[\begin{array}{l}
0 \\
\mathbf{0}
\end{array}\right],\left[\begin{array}{ll}
\sigma_{11} & \boldsymbol{\sigma}_{12}^{\top} \\
\boldsymbol{\sigma}_{12} & \Sigma_{22}
\end{array}\right]
$$

where $\mathbf{x}_{t}=\left[x_{1 t}, x_{2 t}, x_{3 t}\right]^{\top}, \mathbf{b}=\left[b_{1}, b_{2}, b_{3}\right]^{\top}, \mathbf{e}_{t}=\left[e_{1 t}, e_{2 t}, e_{3 t}\right]^{\top}, \boldsymbol{\nu}_{t}=\left[\nu_{1 t}, v_{2 t}, v_{3 t}\right]^{\top}$. In the context of our empirical model, $y_{t}$ denotes real imports, $I M, x_{1}$ denotes real GDP, $Y, x_{2}$ denotes relative prices, $R P$ and $x_{3}$ denotes inequality, $I N$. 
One can make the following remarks regarding the estimators used in our analysis as opposed to the OLS estimator:

(i) The presence of nuisance parameters (cointegration effects) in the asymptotic distribution of the OLS estimator can be due to either (a) Granger causality from $\mathbf{e}_{t}$ to $u_{1 t}$ $\left(\mathbf{a}_{12} \neq \mathbf{0}\right)$, and/or (b) Granger causality from $u_{1 t}$ to $\mathbf{e}_{t}\left(\mathbf{a}_{21} \neq \mathbf{0}\right)$, and/or (c) contemporaneous correlation between $\mathbf{e}_{t}$ and $u_{1 t}\left(\boldsymbol{\sigma}_{12} \neq \mathbf{0}\right)$. In other words, if $\mathbf{a}_{12}, \mathbf{a}_{21}$ and $\boldsymbol{\sigma}_{12}$ were all zero vectors then the OLS estimator would be the optimal estimator for estimating $\mathbf{b} .^{18}$

(ii) The asymptotically efficient estimators, namely JOH, ARDL and FMLS basically deal with the nuisance parameters of the OLS estimator asymptotically. However, in the presence of a small sample some remaining effects may be manifested in biases produced even by JOH, ARDL and FMLS.

(iii) The previous remarks suggest that different estimates among JOH, ARDL and FMLS may arise depending on the relative ability of each estimator to remove the cointegration effects 'relatively fast'. Moreover, if these effects were present only in specific location of the above system, then these estimators would differ only with respect to the corresponding parameter. For example, if only $e_{3 t}$ were either temporally or contemporaneously correlated with $u_{1 t}$ then the estimators are likely to produce different estimates of only say $b_{3}$.

Next, we callibrate the above model using our data. This gives us estimates of $a_{11}$, $\mathbf{a}_{12}, \mathbf{a}_{21}, A_{22}, \sigma_{11}, \boldsymbol{\sigma}_{12}, \Sigma_{22}$. These estimates allow us to simplify our Monte Carlo design, by moving to a lower dimensional model where we have only one regressor. This is due to the fact that our estimates suggest Granger causality and (negative) contemporaneous correlation

\footnotetext{
18 Some further corrections would be necessary for estimating its standard error if $a_{11} \neq 0$.
} 
mainly between $u_{1 t}$ and $e_{3 t}$. As a result, we adopt the following DGP:

$$
y_{t}=\theta x_{t}+u_{1 t}
$$

with $\theta=1$,

$$
\begin{gathered}
x_{t}=x_{t-1}+e_{t} \\
\left(\begin{array}{l}
u_{1 t} \\
e_{t}
\end{array}\right)=\left(\begin{array}{ll}
0.7 & -0.21 \\
0.30 & 0.30
\end{array}\right)\left(\begin{array}{l}
u_{1 t-1} \\
e_{t-1}
\end{array}\right)+\left(\begin{array}{c}
\nu_{1 t} \\
\nu_{2 t}
\end{array}\right)
\end{gathered}
$$

and

$$
\left(\begin{array}{c}
\nu_{1 t} \\
\nu_{2 t}
\end{array}\right) \sim N I I D\left[\left(\begin{array}{l}
0 \\
0
\end{array}\right)\left(\begin{array}{cc}
0.0014 & -0.00019 \\
-0.00019 & 0.00031
\end{array}\right)\right]
$$

Regarding the assesment of our estimators, all estimators of $\theta$ are compared on the basis of the following three statistics:

1) Bias, computed as:

$$
\widehat{\theta}-\theta_{0}
$$

where:

$$
\widehat{\theta}=\sum_{i=1}^{r} \widehat{\theta}_{i} / r
$$

$i=1, \ldots, r$ and $r$ is the number of replications and $\theta_{0}=1$.

2) Average standard error, astde $(\widehat{\theta})$

$$
\operatorname{astde}(\widehat{\theta})=\sqrt{\sum_{i=1}^{r}\left(\widehat{\theta}_{i}-\bar{\theta}\right)^{2} / r}
$$

3) Average root mean squared error, $\operatorname{rmse}(\widehat{\theta})$, computed according to the previous formula in which $\bar{\theta}$ has been replaced by $\theta_{0}$. 
TABLE 3 : Monte Carlo Results

\begin{tabular}{|c|c|c|c|}
\hline & Mean bias & Standard error & Root mean sq. error \\
\hline \multicolumn{4}{|c|}{ Panel A: Sample size $=49$} \\
\hline \multicolumn{4}{|l|}{ Estimator } \\
\hline OLS & -0.0995 & 0.2035 & 0.0513 \\
\hline ARDL & -0.0318 & 0.2266 & 0.0523 \\
\hline JOHANSEN & -0.0115 & 0.2157 & 0.0466 \\
\hline FMLS & -0.0232 & 0.1038 & 0.0113 \\
\hline \multicolumn{4}{|c|}{ Panel B: Sample size: $=490$} \\
\hline \multicolumn{4}{|l|}{ Estimator } \\
\hline OLS & -0.0090 & 0.0200 & 0.0005 \\
\hline ARDL & -0.0004 & 0.0187 & 0.0003 \\
\hline JOHANSEN & -0.0015 & 0.0131 & 0.0002 \\
\hline FMLS & -0.0022 & 0.0124 & 0.0002 \\
\hline \multicolumn{4}{|c|}{ Panel C: Sample size $=4900$} \\
\hline \multicolumn{4}{|l|}{ Estimator } \\
\hline OLS & -0.0010 & 0.0020 & 0.000 \\
\hline ARDL & -0.0001 & 0.0018 & 0.000 \\
\hline JOHANSEN & -0.0002 & 0.0013 & 0.000 \\
\hline FMLS & -0.0002 & 0.0013 & 0.000 \\
\hline
\end{tabular}

The results of 1000 replications of the above model are presented in Table 3. Panel 
A reports simulations results for a sample size of 49 observations. As expected, the OLS appears to be the worst estimator of all, since it exhibits the largest bias and variation. On the other hand, the Johansen specifications consistently outperforms the ARDL procedure in terms of the bias, the standard deviation and root mean square error. However, the fully modified estimator outperforms the ARDL dynamic specification in terms of variation. JOH and FMLS exhibit the lowest bias and variation of all estimators, which implies that it is more likely to be closer to the true value with these two estimators than with any other estimator. In terms of mean bias, the ARDL procedure fairs well in comparison to the simple OLS, but appears to be about three times worse than the Johansen procedure. Thus our results strongly support the superiority of the fully modified estimator and the Johansen estimator for estimation and inference on $\theta$. These procedures appear to be the best since they minimize the corresponding biases and the variation. Note that these procedures also imply the highest inequality elasticity of imports.

Finally, we investigate the effect of the sample size on the estimators' performance. Panel $\mathrm{B}$ and $\mathrm{C}$ report the Monte Carlo results when our sample increases by a factor of 10 in panel B and by a factor of 100 in panel C. As expected, the bias becomes negligible for all the estimators as our sample increases, with only the OLS bias remaining relatively high (OLS does not account for the cointegration effects even asymptotically, although it is super consistent). Moreover, the standard deviation (and the root mean squared error) is almost the same for all estimators. These results are consistent with the relevant asymptotic theory. Indeed, our results show that the bias for all estimators decrease at a rate close to T (instead of $\sqrt{T)}$. For example, the bias of the OLS and FMLS at T=1 is -0.0995 and -0.0232 
respectively, whereas at $\mathrm{T}=10$ the bias decreases to -0.0090 and -0.0022 respectively and at $\mathrm{T}=100$ the bias decreases further to -0.001 and -0.0002 respectively.

\section{Concluding Remarks}

The present paper explains our finding that US income inequality has a significant influence on the US demand for imports on the basis of a model in which trade is conducted in vertically-differentiated products. However, one could advance alternative explanations for this finding. For example, if one assumes that preferences are non-homothetic, and imports have a higher income elasticity than domestically produced goods, then changes in inequality can affect the demand for imports even if trade is conducted in homogeneous goods. Given our objective to improve on the standard specifications of the aggregate import demand function we regard the existence of alternative channels for the influence of inequality on the demand for imports as a plus; after all, despite the increasing importance of verticallydifferentiated products in world trade, the share of international trade that is conducted in either homogeneous goods or in horizontally-differentiated products remains significant.

In this paper, in line with Rose and Yellen (1989), Meade (1992), Johnston and Chinn (1996) and Chinn (2005b), we find no evidence for the existence of a long run relationship between agrregate imports, income and competitiveness in the US. However, the addition of US income inequality as a determinant of the aggregate demand for imports improves the picture significantly. Using US data for the 1948-1996 period we find not only that there is a stable long run relationship between aggregate imports, income relative prices and inequality, but that the influence of inequality is quantitatively very important as well. This result appears robust accross alternative methods of estimating cointegration equations. Moreover, 
Monte Carlo simulations suggest that the methods delivering the highest inequality impact on imports are those with the best performance in small samples.

\section{References}

Acemoglu, D. (2002), "Technical Change, Inequality and the Labor Market", Journal of Economic Literature, 40, 1, pp. 7-72.

Armington, P.S. (1969), "A theory of demand for products distinguished by place of location", IMF Staff Papers, 26, pp. 159-178.

Boyd D., G.M. Caporale and R. Smith (2001), "Real Exchange Rate Effects on the Balance of Trade: Cointegratiopn and the Marshall-Lerner Condition", International Journal of Finance and Economics, 6, pp. 187-200

Bowen, H.P., E. Leamer, and L. Sviekauskas (1987), "Multicountry, Multifactor Tests of the Factor Abundance Theory", American Economic Review, 82, pp. 371-392.

Brandolini A. (1998 ), "A Bird's-Eye View of Long-Run Changes in Income Inequality", Banca d'Italia Research Department.

Chinn, M. (2005a), "Doomed to Deficits? Aggregate U.S. Trade Flows Re-Examined", Review of World Economics, 141(3), pp. 460-485.

Chinn, M. (2005b), "Incomes, Exchange Rates and the U.S. trade Deficit, Once Again", International Finance, 7(3), pp. 1-19.

Creedy, J. (1977), "Pareto and the Distribution of Income," Review of Income and Wealth, 23, pp. 405-411.

Deininger, A. and L. Squire (1996), A new data set measuring inequality, WIDER, Word Bank.

Flam, H. and E. Helpman (1987), "Vertical Product Differentiation and North-South Trade", American Economic Review, 77, pp. 810-822.

Francois, J.and S. Kaplan (1996), "Aggregate Demand Shifts, Income Distribution, and the Linder Hypothesis." Review of Economics and Statistics, 78, 2 , pp. 244-250.

Goldstein, M. and M.S. Khan (1985), "Income and Price Effects in Foreign Trade", in R. W. Jones and P.B.Kenen (eds), Handbook of International Economics, Vol. 2, North-Holland, New York.

Gonzalo, J. (1994), "Five Alternative Methods of Estimating Long-Run Equilibrium Relationships", Journal of Econometrics, 60, 203-233. 
Grossman, G. (1982), " Import competition from developed and developing countries", Review of Economics and Statistics, 64, pp. 271-281.

Hansen, B. (2000), "Sample Splitting and Threshold Estimation", Econometrica, 68, pp.575-603.

Hargreaves, C.P. (1994), "A Review of Methods of Estimating Cointegrating Relationships" in C.P. Hargreaves (ed.), Nonstationary Time Series Analysis and Cointegration, 87-132, Oxford University Press, Oxford.

Helkie, W. and P. Hooper (1988), "An Empirical Analysis of the External Deficit, 1980-86", in R. Bryant, G. Holtham and P. Hooper, External Deficits and the Dollar, Brookings Institution.

Hooper, P., and J. Marquez (1995), "Exchange rates, prices, and external adjustment in the United States and Japan", in Kenen, P. (ed.), Understanding Interdependence, Princeton University Press, Princeton, NJ.

Hooper, P, Johnson K. and J. Marquez (1998), "Trade Elasticities for G-7 Countries", International Finance Discussion Papers No. 609, Federal Reserve Board, Washington D.C.

Houthakker, H., and S. Magee (1969), "Income and price elasticities in world trade", Review of Economics and Statistics, 51, pp.111-125.

Hunter, L. (1991), "The Contribution of Nonhomothetic Preferences to Trade", Journal of International Economics 30, pp. 345-358.

Inder, B. (1993), "Estimating Long-Run Relationships in Economics. A Comparison of Different Approaches", Journal of Econometrics, 57, pp. 53-68.

Johansen, S. (1988), "Statistcal Analysis of Cointegration Vectors", Journal of Economic Dynamics and Control 12, pp. 231-254.

Johansen, S. and K. Juselius (1990), "Maximum Likelihood Estimation and Inference on Cointegration with Application to the Demand for Money", Oxford Bulletin of Economics and Statistics 52, pp. 169-210.

Johansen, Soren, 1991. "Estimation and Hypothesis Testing of Cointegration Vectors in Gaussian Vector Autoregressive Models," Econometrica, 59, pp 1551-80.

Johnston, L.D. and M. Chinn (1996), "How well is America Competing? A Comment on Papadakis", Journal of Policy Analysis and Management 15(1), pp. 68-81.

Katsimi, M. and T. Moutos (2005), "Inequality and Relative Reliance on Tariffs: Theory and Evidence", CESifo Working Paper No. $145 \%$.

Kohli, U.R. (1982), "Relative price effects and the demand for imports", Canadian Journal of Economics, 15, pp. 205-219. 
Krugman, P. (1989), "Differences in Income Elasticities and Trends in Real Exchange Rates", European Economic Review, 33, pp. 1031-1054.

Linder, S. (1961), An Essay on Trade and Transformation, Almqvist and Wiksells, Uppsala.

Malley, J.and T. Moutos, (2002), "Vertical product differentiation and the import demand function: theory and evidence", Canadian Journal of Economics, 35, pp. 257281.

Marquez, J. (2000), "The Puzzling Income Elasticity of US Imports", World Conference of Econometric Society.

Marquez, J. (2002), Estimating Trade Elasticities, Kluwer Academic Publishers, Boston.

Meade, E. (1991), "A Fresh Look at the Resposiveness of Trade Flows to Exchange Rates", Annual meeting of the Western Economic Association.

Mitra, D. and V. Trindade (2003), "Inequality and Trade." NBER Working Paper No. 10087.

Markusen, J. (1986), "Explaining the Volume of Trade: an Eclectic Approach", American Economic Review, 76, 5, pp.1002-1011.

Panopoulou, E. and N. Pittis (2004), "A Comparison of Autoregressive Distributed Lag and Dynamic OLS Cointegration Estimators in the Case of a Serially Correlated Cointegration Error", Econometrics Journal, 7, pp. 585-687.

Pesaran, M.H. and Y. Shin (1999) "An Autoregressive Distributed Lag Modelling Approach to Cointegration Analysis", in S. Strom (ed.) Econometrics and Economic Theory in the 20th Century: The Ragnar Frish Centennial Symposium, Econometric Society Monograph, Cambridge University Press, Cambridge.

Phillips, P.C.B. and B.E. Hansen (1990) "Statistical Inference in Instumental Variables Regression withI(1) Processes," Review of Economic Studies, 57:99-125.

Phillips, P.C.B. (1991) "Optimal Inference in Cointegrated Systems," Econometrica, 59, pp. 283-306.

Phillips, P.C.B. and M. Loretan (1991), "Estimating Long-run Economic Equilibria", Review of Economic Studies, 58, pp. 407-436.

Rose, A. (1991), "The Role of Exchange Rates in a Popular Model of International Trade: Does the 'Marshall-Lerner' Condition Hold?" Journal of International Economics, 30, pp. 301-316.

Rose, A. and J. Yellen (1989), "Is there a J-Curve?", Journal of Monetary Economics, 24 , pp. 53-68. 
Rosen, S. (1974), "Hedonic Prices and Implicit Markets: Product Differentiation in Pure Competition", Journal of Political Economy, 82, pp. 34-55.

Schott, P. (2003), "Across-Product versus Within-Product Specialization in International Trade", Quarterly Journal of Economics, 108, pp. 657-691.

Trefler, D. (1995), "The Case of the Missing Trade and Other Mysteries," American Economic Review, 85, pp.1029-1046. 


\section{CESifo Working Paper Series}

(for full list see www.cesifo-group.de)

1764 Didier Laussel and Raymond Riezman, Fixed Transport Costs and International Trade, July 2006

1765 Rafael Lalive, How do Extended Benefits Affect Unemployment Duration? A Regression Discontinuity Approach, July 2006

1766 Eric Hillebrand, Gunther Schnabl and Yasemin Ulu, Japanese Foreign Exchange Intervention and the Yen/Dollar Exchange Rate: A Simultaneous Equations Approach Using Realized Volatility, July 2006

1767 Carsten Hefeker, EMU Enlargement, Policy Uncertainty and Economic Reforms, July 2006

1768 Giovanni Facchini and Anna Maria Mayda, Individual Attitudes towards Immigrants: Welfare-State Determinants across Countries, July 2006

1769 Maarten Bosker and Harry Garretsen, Geography Rules Too! Economic Development and the Geography of Institutions, July 2006

1770 M. Hashem Pesaran and Allan Timmermann, Testing Dependence among Serially Correlated Multi-category Variables, July 2006

1771 Juergen von Hagen and Haiping Zhang, Financial Liberalization in a Small Open Economy, August 2006

1772 Alessandro Cigno, Is there a Social Security Tax Wedge?, August 2006

1773 Peter Egger, Simon Loretz, Michael Pfaffermayr and Hannes Winner, Corporate Taxation and Multinational Activity, August 2006

1774 Jeremy S.S. Edwards, Wolfgang Eggert and Alfons J. Weichenrieder, The Measurement of Firm Ownership and its Effect on Managerial Pay, August 2006

1775 Scott Alan Carson and Thomas N. Maloney, Living Standards in Black and White: Evidence from the Heights of Ohio Prison Inmates, 1829 - 1913, August 2006

1776 Richard Schmidtke, Two-Sided Markets with Pecuniary and Participation Externalities, August 2006

1777 Ben J. Heijdra and Jenny E. Ligthart, The Transitional Dynamics of Fiscal Policy in Small Open Economies, August 2006

1778 Jay Pil Choi, How Reasonable is the 'Reasonable' Royalty Rate? Damage Rules and Probabilistic Intellectual Property Rights, August 2006 
1779 Ludger Woessmann, Efficiency and Equity of European Education and Training Policies, August 2006

1780 Gregory Ponthiere, Growth, Longevity and Public Policy, August 2006

1781 Laszlo Goerke, Corporate and Personal Income Tax Declarations, August 2006

1782 Florian Englmaier, Pablo Guillén, Loreto Llorente, Sander Onderstal and Rupert Sausgruber, The Chopstick Auction: A Study of the Exposure Problem in Multi-Unit Auctions, August 2006

1783 Adam S. Posen and Daniel Popov Gould, Has EMU had any Impact on the Degree of Wage Restraint?, August 2006

1784 Paolo M. Panteghini, A Simple Explanation for the Unfavorable Tax Treatment of Investment Costs, August 2006

1785 Alan J. Auerbach, Why have Corporate Tax Revenues Declined? Another Look, August 2006

1786 Hideshi Itoh and Hodaka Morita, Formal Contracts, Relational Contracts, and the Holdup Problem, August 2006

1787 Rafael Lalive and Alejandra Cattaneo, Social Interactions and Schooling Decisions, August 2006

1788 George Kapetanios, M. Hashem Pesaran and Takashi Yamagata, Panels with Nonstationary Multifactor Error Structures, August 2006

1789 Torben M. Andersen, Increasing Longevity and Social Security Reforms, August 2006

1790 John Whalley, Recent Regional Agreements: Why so many, why so much Variance in Form, why Coming so fast, and where are they Headed?, August 2006

1791 Sebastian G. Kessing and Kai A. Konrad, Time Consistency and Bureaucratic Budget Competition, August 2006

1792 Bertil Holmlund, Qian Liu and Oskar Nordström Skans, Mind the Gap? Estimating the Effects of Postponing Higher Education, August 2006

1793 Peter Birch Sørensen, Can Capital Income Taxes Survive? And Should They?, August 2006

1794 Michael Kosfeld, Akira Okada and Arno Riedl, Institution Formation in Public Goods Games, September 2006

1795 Marcel Gérard, Reforming the Taxation of Multijurisdictional Enterprises in Europe, a Tentative Appraisal, September 2006 
1796 Louis Eeckhoudt, Béatrice Rey and Harris Schlesinger, A Good Sign for Multivariate Risk Taking, September 2006

1797 Dominique M. Gross and Nicolas Schmitt, Why do Low- and High-Skill Workers Migrate? Flow Evidence from France, September 2006

1798 Dan Bernhardt, Stefan Krasa and Mattias Polborn, Political Polarization and the Electoral Effects of Media Bias, September 2006

1799 Pierre Pestieau and Motohiro Sato, Estate Taxation with Both Accidental and Planned Bequests, September 2006

1800 Øystein Foros and Hans Jarle Kind, Do Slotting Allowances Harm Retail Competition?, September 2006

1801 Tobias Lindhe and Jan Södersten, The Equity Trap, the Cost of Capital and the Firm's Growth Path, September 2006

1802 Wolfgang Buchholz, Richard Cornes and Wolfgang Peters, Existence, Uniqueness and Some Comparative Statics for Ratio- and Lindahl Equilibria: New Wine in Old Bottles, September 2006

1803 Jan Schnellenbach, Lars P. Feld and Christoph Schaltegger, The Impact of Referendums on the Centralisation of Public Goods Provision: A Political Economy Approach, September 2006

1804 David-Jan Jansen and Jakob de Haan, Does ECB Communication Help in Predicting its Interest Rate Decisions?, September 2006

1805 Jerome L. Stein, United States Current Account Deficits: A Stochastic Optimal Control Analysis, September 2006

1806 Friedrich Schneider, Shadow Economies and Corruption all over the World: What do we really Know?, September 2006

1807 Joerg Lingens and Klaus Waelde, Pareto-Improving Unemployment Policies, September 2006

1808 Axel Dreher, Jan-Egbert Sturm and James Raymond Vreeland, Does Membership on the UN Security Council Influence IMF Decisions? Evidence from Panel Data, September 2006

1809 Prabir De, Regional Trade in Northeast Asia: Why do Trade Costs Matter?, September 2006

1810 Antonis Adam and Thomas Moutos, A Politico-Economic Analysis of Minimum Wages and Wage Subsidies, September 2006

1811 Guglielmo Maria Caporale and Christoph Hanck, Cointegration Tests of PPP: Do they also Exhibit Erratic Behaviour?, September 2006 
1812 Robert S. Chirinko and Hisham Foad, Noise vs. News in Equity Returns, September 2006

1813 Oliver Huelsewig, Eric Mayer and Timo Wollmershaeuser, Bank Behavior and the Cost Channel of Monetary Transmission, September 2006

1814 Michael S. Michael, Are Migration Policies that Induce Skilled (Unskilled) Migration Beneficial (Harmful) for the Host Country?, September 2006

1815 Eytan Sheshinski, Optimum Commodity Taxation in Pooling Equilibria, October 2006

1816 Gottfried Haber and Reinhard Neck, Sustainability of Austrian Public Debt: A Political Economy Perspective, October 2006

1817 Thiess Buettner, Michael Overesch, Ulrich Schreiber and Georg Wamser, The Impact of Thin-Capitalization Rules on Multinationals' Financing and Investment Decisions, October 2006

1818 Eric O’N. Fisher and Sharon L. May, Relativity in Trade Theory: Towards a Solution to the Mystery of Missing Trade, October 2006

1819 Junichi Minagawa and Thorsten Upmann, Labor Supply and the Demand for Child Care: An Intertemporal Approach, October 2006

1820 Jan K. Brueckner and Raquel Girvin, Airport Noise Regulation, Airline Service Quality, and Social Welfare, October 2006

1821 Sijbren Cnossen, Alcohol Taxation and Regulation in the European Union, October 2006

1822 Frederick van der Ploeg, Sustainable Social Spending in a Greying Economy with Stagnant Public Services: Baumol’s Cost Disease Revisited, October 2006

1823 Steven Brakman, Harry Garretsen and Charles van Marrewijk, Cross-Border Mergers \& Acquisitions: The Facts as a Guide for International Economics, October 2006

1824 J. Atsu Amegashie, A Psychological Game with Interdependent Preference Types, October 2006

1825 Kurt R. Brekke, Ingrid Koenigbauer and Odd Rune Straume, Reference Pricing of Pharmaceuticals, October 2006

1826 Sean Holly, M. Hashem Pesaran and Takashi Yamagata, A Spatio-Temporal Model of House Prices in the US, October 2006

1827 Margarita Katsimi and Thomas Moutos, Inequality and the US Import Demand Function, October 2006 